\title{
Proqram təminatı işləyən komandaların idarə edilməsi üçün metrikalar
}

\author{
Tofiq Kazımov ${ }^{1}$, Tamilla Bayramova ${ }^{2}$ \\ AMEA İnformasiya Texnologiyaları İnstitutu, Bakı, Azərbaycan \\ ${ }^{1}$ tofigemail.ru, ${ }^{2}$ tamilla@iit.ab.az
}

\begin{abstract}
Xülasə- Məqalədə proqram təminatını işləyən kollektivin peşəkarlığının, onların fərqli bacarıq qabiliyyətinə və təcrübəyə malik olmasının məhsuldarlığa çox böyük təsiri və menecerin rolu haqqında məlumat verilmişdir. İşdə komandanın idarə olunması üzrə prinsiplər göstərilmiş vo əməkdaşların işinin səmərəliliyinin qiymətləndirilməsi üçün yeni metrikalar təklif edilmişdir.
\end{abstract}

Açar sözlor- proqram mühəndisliyi, proqram tominatt, məhsuldarlıq, səmərolilik, menecer, effektivlik göstoricisi.

\section{GİRIS}

Etibarlı proqram təminatının (PT) işlənilməsi üçün müxtəlif ixtisaslı peşəkar və intizamlı komandanın olması vacib şərtlərdən biridir. $\mathrm{Bu}$ komandanın üzvləri tələbləri müəyyən edir, proqram kodunu yazır, sınaqdan keçirir, sənədləşdirir, PT-nin əvvəlcədən müəyyən edilmiş qrafik çərçivəsində yerinə yetirilməsinə nəzarət edir və onu müşayiət edirlər. Layihənin uğur qazanması və ya uğursuz olması bu mütəxəssislərin ideyalarından, peşəkarlığından və əhvaliruhiyyəsindən asılıdır [1].

Deməli, layihənin müvəffəqiyyətli olmasına ən çox təsir edən amillərdən biri insan amilidir. Ona görə də komanda daxilində kiçik qrupların və ya ayrı-ayrı insanların rolu və funksiyaları, onlar arasındakı qarşılıqlı münasibərtlər düzgün qurulmalidir [2].

Kollektivin işinin səmərəliliyini artırmaq üçün onun hər bir üzvünün işi düzgün qiymətləndirilməlidir. Ümumiyyətlə qiymətləndirmə metodları çoxdur. Bunların hər birinin öz mənfi və müsbət cəhətləri var. Qiymətləndirmə üçün hansı metodun seçilməsi rəhbərdən asılıdr. Bu məqalədə proqram təminatının yaradılması üzrə komanda üzvlərinin işinin qiymətləndirilməsi üçün metrikalar işlənilmişdir.

\section{KOMANDANIN İDARӘ OLUNMASI}

Komandanın idarə olunmasının bəzi prinsiplərini aşağıdakı kimi qeyd etmok olar:

- Yaxşı idarə olunan layihə adi icraçılar komandası tərəfindən uğurla yerinə yetirilə bilər;

- Pis idarə olunan layihə peşəkar ekspertlər tərəfindən yerinə yetirildiyi halda belə uğurlu olmayacaq;

- Arxitekturu düzgün işlənib hazırlanmış layihə adi PT yaradıcılari kolektivi tərəfindən də reallaşdırıla bilər;
- Arxitekturu pis işlənib hazırlanmış layihə isə hətta icraçı ekspertləri belə çaşdıra bilər.

Hal-hazırda insanlara rəhbərlik etmə qabiliyyəti rəqabətli bazar şəraitində müvəffəqiyyətin açarı hesab edilə bilər. Bu mürəkkəb məsələləri digər insanların vasitəsilə həll etmək bacarığıdır. Komandanın təşkilində menecerin xüsusi rolunu qeyd etmək lazımdır, çünki onun peşekarlığından, məharət və bacarığından şox şey asılıdır. Kollektiv nəticələr, həmişə fərdi nətcələrdən daha çox əhəmiyyət daşıyır [3].

Göstərilən parametrləri nəzərə alaraq demək olar ki, personalın qiymətləndirilməsi etalonla real fəaliyyətin müqayisə edilməsidir. Personalın qiymətləndirilməsi aşağıda göstərilən məsələləri həll edir [4]:

- qiymətləndirilən işçinin təşkilati strukturda yeri və funksional rolunun seçilməsi, onun inkişafi üçün proqramın işlənilməsi;

- təyin edilmiş meyarlara müvafiq olaraq əmək haqqının müəyyən edilməsi;

- $\quad$ işçini həvəsləndirmə üsullarının (motivasiyası) müəyyən edilməsi.

Personalın qiymətləndirilməsi üçün klassik metodlar aşağıdakı hallar üçün nəzərdə tutulmuşdur [5]:

- $\quad$ stabil təşkilati struktur və bu təşkilatın stabil fəaliyyət növü (bu da tez-tez dəyişən bazara və rəqabətin təzyiqino uyğun deyil);

- $\quad$ rup fəaliyyətinin effektini nəzərə almadan bir işçinin qiymətləndirilməsi.

$\mathrm{Bu}$ deyilənlər təcrübədə mümkün olmadığından halhazırda komandanın işinin səmərəliliyini qiymətləndirmək üçün yeni metod və yanaşmaların işlənilməsi aktual məslələrdəndir. Bu metodlar aşağıda göstərilənlən imkanlara malik olmalıdır [6]:

- komandada olan zəif yerləri aşkar etmək və onları növbəti layihələrdə gücləndirmək;

- komandaların işinin səmərəliliyini öz aralarında müqayisə etmək;

- mükafat fondunu işin səmərəliliyinə görə paylamaq və bu sistemi şəffaf etmək; 


\section{"Informasiya tohlükssizliyinin aktual multidissiplinar elmi-praktiki problemlori” IV respublika konfransl, 14 dekabr 2018-ci il}

- $\quad$ komanda iștirakçılarının bilik səviyyəsinin artırılması üçün sistem işləmək;

- layihələrin idarə edilməsinin mükəmməlik dərəcəsini artırmaq üçün sistemi işləmək;

- müvəffəqiyyətli layihələrin sayını artırmaq, xərcləri azaltmaq.

Təəssüf ki, müasir qiymətləndirmə metodları yuxarıda göstərilən məsələləri həll edə bilmir [7].

\section{PT-ni IŞLӘYӘN KOMANDA ÜZVLORININ SOMORӘLILIYININ QIYMOTLONDİRILMOSI METRIKASI}

Məsələnin qoyuluşu. PT işləyən komanda üzvlərinin hər birini "resurs" adlandıraq və sonrakı mülahizələrdə sadəlik üçün bu termindən istifadə edək. Aşağıdakı resurs tiplərini təyin edək: $M$ - menecer, $T$ - təhlilçi, $P$ - PT-nı işləyən, $S-$ sinaq üzrə mütəxəssis. Resursun effektivliyi universal metrika olub hər dörd $M, T, P, S$ tipli resurslar üçün eyni cür hesablanır. Həm də nəzərdə tutulur ki, resurs ancaq öz kompetensiyasına uyğun və bir istiqamətdə olan məsələlərin həlli ilə məşğul olur. Məsələn, ancaq veb əlavələrin, verilənlər bazasının və ya hesablama modularının işlənilməsi ilə və $\mathrm{s}$. Resursun effektivlik metrikasının əsas komponentlərini göstərək:

- Məsələnin yerinə yetirilmə vaxtı $\left(C_{v}\right.$ əmsalı ilə hesablanır);

- Məsələnin yerinə yetirilmə faktı $\left(C_{f}\right.$ əmsalı ilə hesablanır);

- Səhvlərin sayı ( $C_{s}$ əmsalı ilə hesablanır);

- Resursun effektivliyinin ekspert qiyməti $\left(C_{e}\right.$ əmsalı ilə hesablanır).

İstənilən tip $(M, T, P, S)$ resursun effektivlik göstəricisi $E \epsilon$ $(0 ; 1)$ sadalanan bu komponentləri ozündə cəm edir. Resursun effektivliyini aşağıdakı kimi hesablayaq:

$$
E=\left(C_{v}+C_{f}+C_{s}+C_{e}\right) / 4
$$

burada $C_{v}$ - resursun yerinə yetirilmə vaxtına görə uğurla nəticələnmiş analoji məsələlər (məsələn, veb əlavələr, verilənlər bazası və ya hesablama moduları ) üzrə effektivlik əmsalıdır; $C_{f}$ - resursun məsələni yerinə yetirməsi üzrə effektivlik əmsalıdır; $C_{s}$ - resursun o biri resurslara nisbətən səhv buraxmamaq əmsalıdır; $C_{e}-$ resursun effektivliyinin ekspert qiymətləndirməsini əks etdirən əmsalıdır. $E$-in boyük qiymoti daha yaxşı hesab olunur.

Resursun yerinə yetirilmə vaxtına görə uğurla nəticələnmiș məsələlər üzrə effektivlik əmsalı aşağıdakı formulla hesablanır:

$$
C_{v}=1-V_{2} / V_{l} \text {, }
$$

burada $V_{l}=\left(T_{1}-T_{2}\right) / N_{v}$ - resursun uğurla nəticələnmiş məsələlər üzrə yerinə yetirilmə vaxtının orta qiymətidir; $N_{v}$ resursun uğurla nəticələnmiş məsələlərinin sayıdır; $T_{1}$ resursun uğurla nəticələnmiş məsələlərinin ümumi yerinə yetirilmə vaxtıdır; $T_{2}$ - resursun uğurla nəticələnmiş məsələləri yerinə yetirərkən fasilələrinin ümumi vaxtıdır; $V_{2}=\left(T_{1 a^{-}}\right.$ $\left.T_{2 a}\right) / N_{v a}$ - resursun uğurla nəticələnmiş analoji məsələlər üzrə yerinə yetirilmə vaxtının orta qiymətidir; $N_{v a}$ - resursun uğurla nəticələnmiş analoji məsələlərinin sayıdır; $T_{l a}$ - resursun uğurla nəticələnmiş analoji məsələlərinin ümumi yerinə yetirilmə vaxtıdır; $T_{2 a}$ - resursun uğurla nəticələnmiş analoji məsələləri yerinə yetirərkən fasilələrinin ümumi vaxtıdır; $C_{v} \epsilon$ $[0 ; 1]$ və boyük qiyməti daha yaxş1 hesab olunur.

$C_{f}$ - resursun məsələləri yerinə yetirməsi üzrə effektivlik əmsalı aşağıdakı düsturla hesablanır:

$$
C_{f}=\left(a_{1} N_{1}+a_{2} N_{2}+a_{3} N_{3}+a_{4} N_{4}\right) / N,
$$

burada $N_{l}$ - vaxtında yerinə yetirilmiş məsələlərin sayıdır; $N_{2}$ vaxtından qabaq yerinə yetirilmiş məsələlərin sayıdır; $N_{3}$ vaxtından gec yerinə yetirilmiş məsələlərin sayıdır; $N_{4}$ - yerinə yetirilməmiş məsələlərin sayıdır; $N$ - resursla bağlı məsələlərin ümumi sayıdır; $a_{1}, a_{2}, a_{3}, a_{4}-N_{1}, N_{2}, N_{3}, N_{4}$ üçün çəki əmsallarıdır. $a_{1}, a_{2}, a_{3}, a_{4}$ əmsallarının qiymətləri expert qiymətləndirilməsi əsasında müxtəlif layihə və proseslərdə variativ surətdə müəyyən oluna bilər.

$a_{1}, \quad a_{2}, \quad a_{3}, \quad a_{4}$ əmsallarının expert qiymətləndirilməsi əsasında hesablanmasının bir sadə varinantını göstərək. Tutaq ki, $\delta=1,2,3 \ldots$ sayda expertin $N_{l}, N_{2}, N_{3}, N_{4}$ məsələləri üzrə $\lambda$ ballı sistemdə qiymətləndirməsi var. Onda $a_{j}(j=1, \ldots, 4)$ belə hesablana bilər:

$$
a_{j}=\frac{1}{\delta \lambda} \sum_{i=1}^{\delta} p_{i j}, \quad j=1, \ldots .4
$$

burada $p_{i j}-i$-ci expertin $j$-ci məsələ üzrə qiymətləndirməsidir.

Məsələn, praktiki məsələlərdə $a_{1}, a_{2}, a_{3}, a_{4}$ əmsalları üçün $a_{1} \epsilon[0,9 ; 1,1], \quad a_{2} \epsilon[1,2 ; 1,5], \quad a_{3} \epsilon[0,6 ; 0,8], \quad a_{4} \quad \epsilon[0,2 ; 0,5]$ intervalları müəyyən oluna bilər.

Resursun o biri resurslara nisbətən səhv buraxmamaq əmsalı $C_{s}$ aşağıdakı düsturla hesablanır:

$$
C_{s}=1-H_{s} / H_{u},
$$

burada $H_{s}$ - resursun əvvəllər yerinə yetirdiyi bütün məsələlər üzrə buraxdığı səhvlərin ümümi sayıdır; $H_{u}$ - bütün resursların yerinə yetirdiyi bütün məsələlər üzrə buraxdığı səhvlərin ümümi sayıdır. $C_{s} \epsilon[0 ; 1]$ və boyük qiyməti daha yaxşı hesab olunur.

$C_{e}-$ resursun effektivliyinin ekspert qiymətləndirməsini əks etdirən əmsalı aşağıdakı düsturla hesablanır:

$$
C_{e}=\frac{1}{\lambda^{3} \delta^{3}} \prod_{j=1}^{3} \sum_{i=1}^{\delta} b_{i j},
$$




\section{"Informasiya tohlükssizliyinin aktual multidissiplinar elmi-praktiki problemlori” IV respublika konfransl, 14 dekabr 2018-ci il}

Burada $\delta$ - ekspertlərin say1; $b_{i 1}-i$-ci expertin resursun məsələləri yerinə yetirmə sürətinə verdiyi qiymətdir; $b_{i 2}-i$-ci expertin resursun məsələləri yerinə yetirmə keyfiyyətinə verdiyi qiymətdir; $b_{i 3}$ - $i$-ci expertin resursun bilik və bacarığına verdiyi qiymətdir; $C_{e} \epsilon[0 ; 1]$ və boyük qiyməti daha yaxşı hesab olunur və işçilərin əməyinin qiymətləndirilməsi zamanı əsas göstərici kimi istifadə edilə bilər.

\section{NəTİCə}

Təklif olunan yanaşma PT icraçılarının işinin effektivliyini qiymətləndirməyə və eyni zamanda hansı məsələnin hans1 icraçı tərəfindən daha tez və effektiv yerinə yetirilməsini müəyyən etməyə imkan verir. Bu yanaşmanın köməyi və qurulan imitasiya modeli vasitəsilə PT-nın islənilmə prosesini proqnozlaşdıraraq qəbul olunan qərarların effektıvliyini qiymətləndirmək olar.

Lakin istənilən halda işin spesifikasiyası, komandanın xüsusiyyətləri və kollektivdə olan münasibətlər də nəzərə alınmalıdır. Ogər əməkdaş əmin olsa ki, onun işinə qiymət verirlər, o nəinki kollektivi və şirkəti pis vəziyyətə qoymaz, həm də mümkün qədər çox xeyir gətirər.

İstənilən şirkətin müvəffəqiyyətlə işlədiyinin əsas göstəricisi onun əldə etdiyi gəlirdir. $\mathrm{Bu}$ da məhsulun və ya xidmətin istehsalı üçün mövcud resurslardan səmərəli istifadə edilməsi və personalın işinin düzgün təşkil edilməsindən asılıdr. Ona görə də işçilərin işinin düzgün qiymətləndirilməsi və ölçülməsi hal-hazırda vacib problemlərdən biridir.

\section{ӘDӘBIYYYAT}

1. Лаврищева Е.М., Петрухин В.А. Методы и средства инженерии программного обеспечения: Учебное пособие. М.:МФТИ, 2007, 415 с.

2. Фищенко К. С. Оценка эффективности работы персонала // Актуальные вопросы экономики и управления: материалы Междунар. науч. конф. Москва, апрель 2011 г.Т. II., М.: РИОР, 2011. c. 68-70. https://moluch.ru/conf/econ/archive/9/458/

3. Boehm B. W.. Software engineering economics. Manuscript received april 26, 1983, The author is with the Software Information Systems Division,TRW Defense Systems Group, Redondo Beach, CA 90278. pp. 150.

4. Веснин B.Р. Управление персоналом. Теория и практика: электронный учебник. М., 2009.

5. Уилсон С.Ф., Мэйплс Б., Лэндгрейв Т. Принципы проектирования и разработки программного обеспечения. М., 2002.

6. Жаркова Г. А. Современные системы автоматизации разработки информационных систем: учебно-методическое пособие. Ульяновск: УлГУ, 2007.

7. Development Leaders Reveal the Best Metrics for Measuring Software Development Productivity, 2017, https://stackify.com/measuring-software-developmentproductivity/

\section{METRICS FOR EVALUATING THE WORK OF SOFTWARE DEVELOPMENT TEAM MEMBERS \\ Tofig Kazimov $^{1}$, Tamilla Bayramova ${ }^{2}$ \\ ${ }^{1,2}$ Institute of Information Technology of ANAS, Baku, Azerbaijan \\ ${ }^{1}$ tofig@mail.ru, ${ }^{2}$ tamilla@iit.ab.az} large impact on the productivity of software product development, qualifications, personal qualities and experience of software developers, and emphasizes the leading role of the manager. This paper shows the principles of team management and provides metrics for evaluating team performance.

Keywords- - software engineering, software, productivity, efficiency, manager, effectiveness indicator. 